\title{
Organisational learning capabilities as determinants of social innovation: An empirical study in South Africa
}

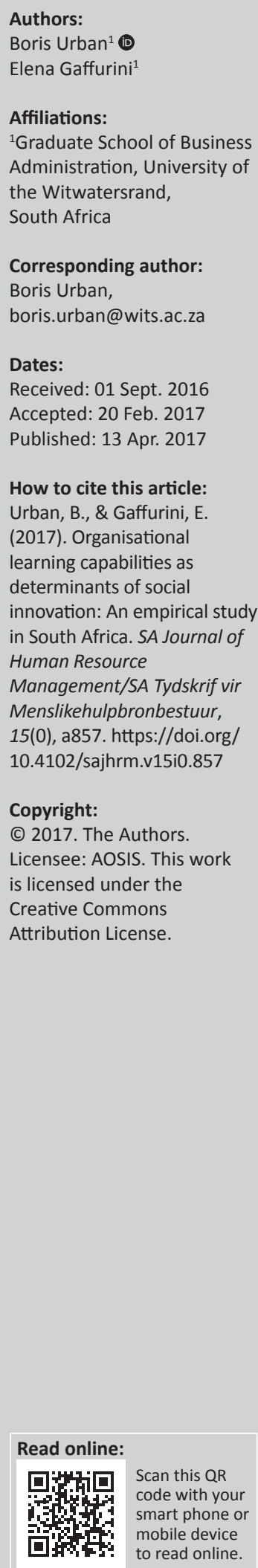

Orientation: A critical reading of the human resource management (HRM) literature finds limited contributions to understanding the organisational determinants of social enterprises and how these may contribute to higher levels of social innovativeness. Although innovation is a key theme in organisational research it has been acknowledged that the field needs more theory-based examinations of different types of innovativeness.

Research purpose: To determine how different organisational capabilities are related to social innovation.

Motivation for the study: Many social enterprises in developing countries do not have the requisite capabilities to efficiently manage all their programmes, which presents a major threat to organisational sustainability.

Research design, approach and method: The empirical analysis is a cross-sectional study based on primary survey data. Hypotheses are tested using correlational and regression analysis.

Main findings: The results show that the organisational learning capabilities of knowledge conversion, risk management, organisational dialogue and participative decision-making all have a significant and positive relationship with social innovation.

Practical/managerial implications: Managers and practitioners can leverage the different organisational learning capabilities to improve social innovations in their social enterprises.

Contribution/value-add: The study is one of the first in an African market context to empirically investigate social enterprises in terms of social innovation and organisational learning perspectives.

\section{Introduction}

Growing interest has been placed on social entrepreneurship (SE) as an innovative way to incorporate economic activities into providing solutions for social problems, and in the process adding social value (Porter \& Kramer, 2011). Indeed, both practitioners and scholars note that the pursuance of financial worth without reference to social value creation is becoming increasingly difficult (Nicholls, 2014). Several researchers and practitioners are advocating that social enterprises could pave the way to a more sustainable and fair society, built on the basis of satisfying local needs and the creation of innovative market-orientated solutions (Nicholls, 2006; Urban, 2015).

SE has gained popularity under shifting market conditions and can be viewed as a process that catalyses social change (Jiao, 2011; Mair \& Marti, 2006). Social entrepreneurs, virtually by definition, are attacking social problems caused by shortcomings in existing markets and social welfare systems and seek to create systemic changes and sustainable improvements (Bacq \& Janssen, 2011; Weerawardena, McDonald \& Mort, 2010). They engage in a process of 'continuous innovation, adaptation, and learning; acting boldly without being limited by resources currently in hand and exhibit heightened accountability to the constituencies served and for the outcomes created' (Dees, Emerson \& Economy, 2001, p. 2).

Scholarly interest in SE has progressed beyond the early focus on definitions and context to investigate the management and performance of social enterprises (Littlewood \& Holt, 2013; Urban, 2015). Prior studies have focused on how social enterprises have developed innovative strategies (Weerawardena \& Mort, 2006); formulated new resource configurations (Austin, Stevenson \& Wei-Skillern, 2006); found new ways to advance social change (Dees, 2007); established new business models (Michelini \& Fiorentino, 2012); understood the role of power in 
social innovations (Dover \& Lawrence, 2012); and hold the requisite mix of managerial and entrepreneurial skills (Urban, 2008).

However, a critical reading of the human resource management (HRM) literature revealed a dearth of contributions to understanding the organisational determinants and processes of SE and how these may contribute to higher levels of social innovativeness. Although innovation is a key theme in SE research it has been acknowledged that the field needs more theory-based examinations of innovativeness (Newth \& Woods, 2014). SE not only has direct relevance to developed countries, but also to emerging markets, where social issues have unequivocal application since traditional government initiatives are unable to satisfy the entire social deficit (Rwigema, Urban \& Venter, 2010).

The study responds directly to recent research calls to provide a much needed account of current thinking on theoretical and practical problems on innovativeness and organisational aspects of social enterprises. The problem prompting this study is that many social enterprises in developing countries do not have the time and expertise to efficiently manage all their programmes, which presents a major threat to organisational sustainability (Dacin, Dacin \& Tracey, 2011; Weerawardena et al., 2010). Considering the dearth of capabilities in the African formal sector (Zoogah, Peng \& Woldu, 2015), the effectiveness of African organisations is severely limited.

Insights are drawn upon from earlier work which advocates that social enterprises need to adopt market-orientated approaches and subsequently need to develop organisational learning capabilities to adapt to dynamic environments, while simultaneously creating social innovations and delivering social value (e.g. Chalmers \& Balan-Vnuk, 2013). Organisational learning capability (OLC) for the purpose of this study implies experimentation through searching for innovative solutions to social challenges and requires support for creativity and tolerance for failure to enhance the social enterprises' adaptability to the external environment (Chiva \& Alegre, 2009). Building on the theoretical roots of organisational and innovation studies (Hoogendoorn \& Pennings, 2010), hypotheses are formulated to empirically test the relationship between different dimensions of OLC and social innovation of social enterprises.

SE, non-profit and philanthropic studies are a relatively new area of study, and consequently the emphasis of many publications has tended to be focused on issues of definition and theory with designs that rely on anecdotal evidence, without supporting empirical research (Helm \& Andersson, 2010). Consequently, this study makes the following contributions to the literature on organisational learning and social enterprises. Firstly, it adds to the literature by focusing on OLC towards explaining levels of social innovation in social enterprises. In this regard, the study will address the current issues on organisational aspects in Africa and rely on the theory of organisational learning to understand its influence on social innovation. Secondly, the study takes place in an under-researched country, South Africa, a nonwestern context where social problems are exacerbated by a social context characterised by massive inequalities in education, housing, the HIV and/or AIDS pandemic, and high unemployment and poverty rates (Rwigema et al., 2010). The study will be one of the first in an African market context to empirically investigate social enterprises from a social innovation and OLC perspective. Thirdly, the study has implications for managers and practitioners who need to take into account the configuration of OLC factors which influence higher levels of social innovations.

This article is structured as follows: The first section describes the theoretical foundations underlying the analysis and derives hypotheses for empirical testing. The second section introduces the methodological design of the empirical work which is based on primary survey data. And the third section presents the results of the statistical analysis, while the final section discusses the findings and their implications for policy and further research.

\section{Literature review}

\section{Social entrepreneurship and social innovation}

$\mathrm{SE}$ is an extended concept of entrepreneurship (Drucker, 1986) and has in recent decades gained momentum as a means to address social challenges within society (Nicholls, 2011). This is evident in philanthropic efforts, not-for-profit organisations (NPOs) and non-governmental organisations (NGOs), as well as corporate social initiatives, all of which are social interventions that attempt to address social inequities that may exist within a society (Dees et al., 2001).

Conceptual differences are noticeable in definitions of SE (focus on process or behaviour), social entrepreneurs (focus on founder of initiative), and social enterprise (focus on tangible outcome of SE). Further reflection on the SE academic literature reveals a number of themes, preoccupations and domains (Weerawardena \& Mort, 2006); broadly these are: (1) SE may be expressed in a vast array of economic, educational, welfare, and social activities, reflecting diverse initiatives and activities, (2) SE may be conceptualised in a number of contexts, that is public sector, community, and social action organisations and (3) the role of innovativeness, proactiveness and risk taking in SE have been emphasised in distinguishing SE from other forms of community work.

Increasing research is taking place on the social enterprise as a vehicle to drive social innovations (Porter \& Kramer, 2011). However, the same importance of innovativeness has also been assigned to social enterprises, where it is suggested that they need to adopt a market and entrepreneurial posture (Weerawardena \& Mort, 2001), in order to engage in innovative practices (McDonald, 2007). Innovation is a key determinant of survival for social enterprises just as it is for traditional businesses (Jaskyte \& Dressler, 2005).

Social innovation is the outcome of a new way of thinking and acting, which materialises through new social movements, 
institutions, social practices or even different structures of collaborative work (Cajaiba-Santana, 2014). Social innovation is conceptualised as more ambiguous and complex than conventional innovation as applied by commercial ventures, because of the higher number of stakeholders having different interests, value sets and priorities (Lettice \& Parekh, 2010).

The importance of the relationship between social innovation and organisational learning is underscored when considering that if knowledge and innovation do not circulate effectively in a social enterprise, there is a high probability of wasteful resources that may negatively affect the community and hinder the potential to scale the social innovation (Dees, 2009). Indeed, innovation pursued in the absence of knowledge regarding what is already in place is not innovation but rather duplication and useless efforts amounting to little more than multiple reinventions of existing wheels (Nicholls, 2006).

\section{Organisational learning}

Research on organisational learning has progressed exponentially in recent years (Easterby-Smith, Crossan \& Nicolini, 2000). Beginning with the notion of learning as being primarily cognitive and simply equal to the sum of learning of individuals (Simon, 1991), research has progressed to recognise organisational learning as being socially constructed and situated (Lave \& Wenger, 1991) in the learning activities of individuals, groups, organisations and inter-organisational networks. Different schools of thought in organisational learning have been noted; these include the economic (learning based on experience and production), the developmental (the learning organisation being a stage in the evolution of the firm), the managerial (concerned with prescriptive learning outcomes) and the process (learning as socially constructed and grounded in the cognitive and behavioural capability of individuals) (Bell, Whitwell \& Lukas, 2002).

Organisational learning has also been related to the entrepreneurship where Dutta and Crossan's (2005) 4I (Intuiting, Interpreting, Integrating, and Institutionalising) organisational learning framework yields insights about the processes that comprise the life cycle of the entrepreneurial opportunity construct. The 4 I framework recognises that a critical part of learning occurs when the individuals develop insights based on their intuitive patterns relating to the emerging business environment.

From a resource-based view (RBV), organisations achieve sustained competitive advantage through firm-specific resources and capabilities that are valuable, rare, hard to imitate and organisationally embedded (VRIO) (Barney, 2001). Organisations that can configure their resources and capabilities in ways that enable them to overcome the constraints of the complex and unpredictable environment are likely to achieve short-term and long-term outcomes (Zoogah et al., 2015). Similarly, OLC from the RBV lens may be considered as a bundle of intangible and tangible competencies and resources used by organisations to obtain several benefits when transforming the outcome of the acquisition of knowledge into rare, valuable, non-substitutable and inimitable routine procedures (Chiva \& Alegre, 2009).

OLC provides an indication of the potential to innovate and grow (Jerez-Gómez, Céspedes-Lorente \& Valle-Cabrera, 2005) which encompasses several subprocesses, and is considered a complex and multi-dimensional construct (Chalmers \& Balan-Vnuk, 2013). Several studies have identified different dimensions of OLC which include activities that people need to be involved so that organisations become learning organisations (Watkins \& Marsick, 1996), as well as in the context of entrepreneurship, social enterprises and government organisations (Alegre, Chiva, Gobert \& Lapiedra, 2008; Chiva \& Alegre, 2009; Visser, 2009). The dimensions of OLC include: continuous learning, inquiry and dialogue, empowerment, strategic leadership, managerial commitment, openness and experimentation, knowledge transfer and integration, risk management, interaction with the environment, organisational dialogue and participative decision-making.

Building on in this research direction several key dimensions of OLC are operationalised for the purpose of this study which have been previously identified in the literature. Notwithstanding the complexity of the phenomenon and the reciprocal nature of relationships between these dimensions and social innovation, hypotheses are formulated but are restricted to a number of dimensions (knowledge conversion, experimentation, risk management, networking, dialogue and participative decision-making). These OLC dimensions which inform the hypotheses are examined below.

Knowledge conversion: Knowledge conversion and its effective utilisation at the organisational level have been identified as an important conduit that fosters idea creation and enhances innovation (Gunsel, Siachou \& Acar, 2011). An organisational design that is conducive to optimising knowledge work expertise (Ramsey \& Barkhuizen, 2011), where the process of knowledge conversion creates valuable intangible assets that form part of the capital base of the organisation is considered a driving force for innovation. Cabrita and Vaz (2005) point out that knowledge generation and conversion is dependent on the individual's willingness. Research finds that the timely combination of internally generated and externally acquired knowledge with existing products and services in creative ways is a source of competitive advantage for hybrid enterprises and assists in delivering on increased social innovation (Escobar, Gutierrez, Gutierrez \& Carlos, 2011). Following these theoretical and empirical findings, in the first instance it is hypothesised that:

- Hypothesis 1 (H1): The OLC dimension of knowledge conversion is positively related with levels of social innovation in social enterprises.

Experimentation: Experimentation as a series of trial and error changes, which includes the process of learning from 
failure (Pretorius \& Le Roux, 2011), can be pursued along various dimensions of strategy, and helps an organisation to develop a competitive advantage (Sarasvathy \& Venkataraman, 2011). OLC implies experimentation through searching for innovative solutions to social challenges and requires support for creativity and tolerance for failure (Chiva \& Alegre, 2009). Experimentation involves curiosity, testing of new ideas and implementing changes in operational processes, and materialises through incremental changes fostering a creative environment (Mthanti \& Urban, 2014). For social enterprises, experimentation implies developing creative and sustainable ideas to solve a broad range of issues affecting society as well as improving the well-being of individuals (Bulut, Eren \& Halac, 2013). Consequently, it is hypothesised:

- Hypothesis 2(H2): TheOLC dimension of experimentation is positively related with levels of social innovation in social enterprises.

Risk management: Creating new products or services, or new ways of delivery are required by social entrepreneurs to satisfy the needs embedded in the social market (Mair \& Marti, 2006), specifically in the process bringing about social change (Urban, 2015). Social enterprises are accountable to their funders and donors, as well as to the communities to whom they present their products and services with a unique selling proposal focused on delivering social value. In this regard, Weerawardena and Mort (2006) proposed that social entrepreneurs have risk-management qualities, instead of their risk-taking qualities, as do their commercial counterparts. Social enterprises constantly seek new approaches to intervene in solving social issues which reflects a level of risk bearing in light of promoting social innovation (Hoogendoorn \& Pennings, 2010). Against this background, it is hypothesised that:

- Hypothesis 3 (H3): The OLC dimension of risk management is positively related with levels of social innovation in social enterprises.

Networking: Social entrepreneurs generate value from social networks they can access, particularly in terms of acquiring ideas, attracting talent and resources (Jiao, 2011). OLC may be reinforced by the interaction of social enterprise actors with external stakeholders, through a complex structure of boundaries and agents who can bridge the gaps due to the inherent diversity in the external environment (Tandon, 2014). Failing to connect to the right network may limit access to resources and lower the morale of the staff, thereby hindering the capability to successfully innovate (Lettice \& Holt, 2010). Acquiring knowledge through collaboration and interacting with the external environment allows for effective partnerships to evolve which in turn enhances the capability of an organisation to generate social innovation (Chalmers \& Balan-Vnuk, 2013). Following this line of reasoning, it is anticipated that:

- Hypothesis 4 (H4): The OLC dimension of networking is positively related with levels of social innovation in social enterprises.
Organisational dialogue: Seelos and Mair (2012) highlight the importance for social enterprises to develop capabilities such as absorptive capacity and knowledge management, which often evolve through sustained dialogue (Tandon, 2014). Implementing knowledge management initiatives, building project databases, and fostering dialogue internally and externally generally enhance the capability of the organisation to generate social innovations (Chalmers \& Balan-Vnuk, 2013). Social entrepreneurs who foster innovativeness leverage the intellectual stimulation of their collaborators and employees, and seek to create a feeling of unity while fostering dialogue and commitment towards the achievement of the organisational vision (Jaskyte, 2004). Moreover, in social enterprises learning is likely to occur when different departments and teams interact through sustained dialogue with each other (Tandon, 2014). Building in this direction, it is hypothesised that:

- Hypothesis 5 (H5): The OLC dimension of organisational dialogue is positively related with levels of social innovation in social enterprises.

Participative decision-making: Studies indicate that an organisational structure facilitating inclusive decisionmaking practices supports organisational learning and innovation (Chiva, Alegre \& Lapiedra, 2007). Promoting learning and participative decision-making among employees can enhance their engagement and increase their sense of belonging to the organisation, therefore fostering a culture of alertness to new opportunities and innovations (Marques, 2007). Findings, such as from the World Economic Forum (2014), highlight that individuals are most confident about social enterprise leaders because these leaders are trusted to act in the interests of the marginalised and under-represented. Based on these findings it is hypothesised that:

- Hypothesis 6 (H6): The OLC dimension of participative decision-making is positively related with levels of social innovation in social enterprises.

These hypothesised relationships are illustrated in Figure 1. The hypotheses and model structure are tested statistically in the following sections.

\section{Methodology Data collection and sampling}

The present article is a cross-sectional study utilising survey data to test the hypotheses formulated. The primary selection criteria in choosing participants are that they should be involved in an enterprise with social profit goals and revenue should be used to support social goals instead of shareholder returns (Harding, 2006).

Similar to other studies, the lack of a legal framework identifying social enterprises did not allow for the identification a priori among the population (Chiva \& Alegre, 2009). Consequently, in recognising these limitations, social enterprises operating in South Africa based on a sampling frame from the South African social innovation and 


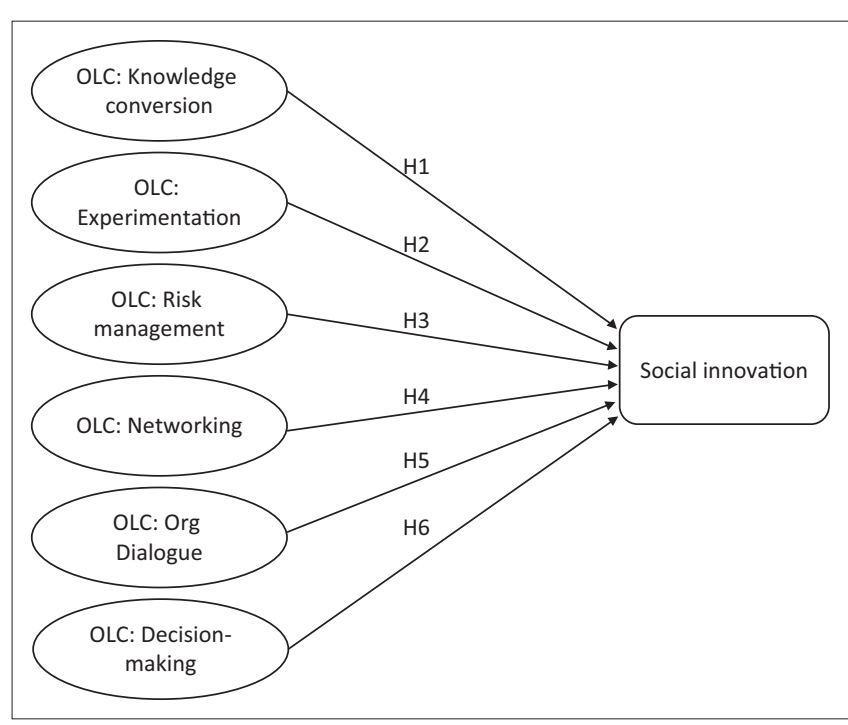

OLC, Organisational learning capability.

FIGURE 1: Conceptual model of organisational learning capability dimensions and social innovation.

entrepreneurship (SASIE) network database (Holt, 2016) were accessed, where respondents included field workers, social enterprise managers and project managers.

The unit of analysis was the individual as they typically hold some levels of decision-making power and are engaged in strategic discussions for their respective organisations. Based on the sampling selection criteria an electronic survey yielded a total of 577 qualifying individuals which were coded into a database where a random-numbers program was applied to randomly select individuals across the surveyed social enterprises. This multistage screening rendered a final sample of 135 complete responses, yielding a $23.4 \%$ response rate. This was regarded as a reasonable response rate, given that a number of emails did not reach the recipients presumably because of staff mobility, error in capturing email addresses and/or strict email policy among the organisations surveyed (Cooper \& Schindler, 2011).

\section{Instruments}

The research survey design was an interview questionnaire consisting of three separate sections reflecting the constructs under study. Care was taken to ensure clarity in terminology and to ensure that the items in the questionnaire addressed the hypotheses. Existing instruments were scrutinised for suitability and the survey operationalised with the theoretical constructs discussed in the literature. All items were measured along a seven-point Likert-type scale, ranging from 'mostly disagree' $=(1)$ to 'mostly agree' $=(7)$. Ethical considerations were taken into consideration by ensuring that the instrument used posed no risk or danger to respondents. The study purpose and benefits to the sample population as well as the participant's rights and protections were made explicit and explained to the respondents at the start of the data collection process. Furthermore, full and open information (informed consent) was made available to respondents, to ensure that no form of deception and misrepresentation was used to extract information from the respondents and their privacy and confidentiality was respected at all times.

The first section of the instrument consisted of multi-variables used to assess OLC (as the independent variables [IVs]) by measuring the dimensions in line with the hypotheses. The manifest variables were operationalised based on the following six OLC dimensions identified in prior studies and as conceptualised in the literature review (Chalmers \& BalanVnuk, 2013; Chiva \& Alegre, 2009; Visser, 2009): (1) experimentation as the extent to which new ideas and suggestions are accepted and tested (3 items); (2) risk management as the tolerance for ambiguity, uncertainty and errors (3 items); (3) knowledge conversion as learning from past errors and dissemination of knowledge across the organisation through systems, training, formal and informal networks (4 items); (4) the external environment as the scope of the relations nurtured by the environment where the organisation operates (4 items); (5) dialogue as the collective inquiry into processes and assumptions of routine activities (4 items) and (6) participative decision-making as the level of influence assigned to employees along the decision-making process (3 items).

The second section focused on social innovation (as the dependent variable [DV]) of social enterprises. Several instruments were scrutinised for suitability, and in the final instance a social innovation index was used which focuses on supporting the development of local solutions to global problems by facilitating collaboration and hybridisation across sectors (Innobasque, 2013). The index was developed with the intent of allowing its customisation to fit different sectors, namely businesses, universities, technological centres and NPOs. Eleven items were used to measure social innovation, which included items relating to project development, impact and governance as indicators of an organisation's ability to enact social innovation (Innobasque, 2013).

Control variables included respondent's years of tenure in the organisation, educational background and work position, all of which have previously been linked to SE (Harding, 2006).

\section{Data analysis}

As the study used a self-report questionnaire to capture the individual-level measures at one point in time, common method bias may have affected the results and conclusions. A number of procedural and statistical steps were taken to minimise this risk. Procedurally, to reduce socially desirable responses and item ambiguity, the questionnaire featured specific, clear, concise items, with a 'counter-balanced' question order, and the respondents could choose to remain completely anonymous (Podsakoff, Mackenzie, Lee \& Podsakoff, 2003, p. 888). Statistically, to ensure rigour in the results all items relating to the IVs and DVs were explored in a single principal component analysis (PCA), using Harman's one-factor test (Podsakoff et al., 2003) to check if one 
component accounted for most of the variance. Five components with eigenvalues greater than 1.0 were detected, which accounted for $63 \%$ of the variance. The largest component accounted for only $11 \%$. These results suggest that common method bias was not identified and is not a serious concern in this study.

Furthermore, exploratory factor analysis (EFA) was applied to determine the dimensionality of the constructs of the model, followed by correlational and linear regression analysis to test the hypotheses as per the conceptual model.

\section{Results \\ Sample characteristics}

The majority of the respondents (42\%) had worked at the current social enterprise for less than 12 months, while $26 \%$ had worked for a period of 1-3 years. In terms of work position, $48 \%$ of the respondents were field workers directly involved with the target community, 29\% were project managers liaising with head office and local branches in the delivery of social projects and initiatives, and $16 \%$ of the respondents were senior managers focused on the development of new strategies and the governance of the organisation, while $7 \%$ were external consultants hired on a temporary contract basis. Furthermore, $44 \%$ of the sample had completed high school, while $48 \%$ had university education, with $4 \%$ of the sample holding postgraduate qualifications.

\section{Measurement validity and reliability tests}

Initially the adequacy of the intercorrelations across all OLC items was checked with Bartlett test of sphericity, and the sampling adequacy was tested through the Kaiser-MeyerOlkin (KMO) measure. Both the results were significant $(p<0.001)$ and the obtained KMO value of $0.88\left(x^{2}=162.09\right)$ provided support for the adequacy of conducting factor analysis.

EFA using the principal axis factoring method with Harris Kaiser Case II rotation was used. Eigenvalues $>1$ and factor loadings of $\geq 0.5$ were regarded as significant (Hair, Black, Babin \& Anderson, 2010). Based on the literature review, six factors were expected to underlie the items measured, and subsequently to load on a second-order factor describing the construct of OLC as conceptualised for this study. After several attempts at factor analysis, using the scree plot method of factor extraction, the presence of five factors with eigenvalues $>1$ were detected. However, some of the items did not load consistently or did not load at all. The loadings on two of the factors were extremely weak with several crossloadings of items.

Subsequently, a four-factor solution was extracted with significant factor loadings, explaining $80 \%$ of cumulative variance. Based on the results of this factor analysis, the constructs as originally conceptualised were all retained apart from experimentation and networking. The extracted factors were subsequently identified as IVs representing the theoretical constructs of: (Factor 1) knowledge conversion, (Factor 2) risk management, (Factor 3) organisational dialogue and (Factor 4) participative decision-making. These results ensured that four $(\mathrm{H}, \mathrm{H} 3, \mathrm{H} 5, \mathrm{H} 6)$ out of the original six hypotheses were now tested further.

The same procedure was conducted to establish construct validity of the DV - social innovation. Based on the scree plot method of factor extraction, the presence of one factor, with an eigenvalue $>1$, was detected which explained $89 \%$ of total variance. EFA results showed that all the items loaded $(\geq 0.50)$ on one unique factor measuring social innovation, and consequently it was decided to treat social innovation as a unique construct.

To assess the reliability of the scales, Cronbach's alpha coefficients were calculated on the factors identified through the EFA results. Table 1 shows the number of items per construct scale, the average inter-items total correlation and the Cronbach's alpha coefficients for each construct. These alpha values were all deemed to be reliable as they exceed the suggestion of 0.70 for exploratory research by Nunnally (1978). Thereafter, the scales were aggregated by averaging the multi-item scores for each observation into a final variable score, which was used in subsequent analyses.

\section{Descriptive statistics and correlations}

Descriptive statistics are shown in Table 2, where the overall mean scores for the various factors were relatively high, indicating agreement with the scale, and exceeded the midpoint average on the 1-7 Likert scale. Thus the responses to these scales are generally positive or very positive, an observation consistent with the skewness of the scales. The highest mean score was for social innovation $(M=5.64$, $\mathrm{SD}=0.97)$. The standard deviations of all OLC scores exceeds 1.00 , suggesting relatively high variation across the responses.

Comparisons of means tests were conducted to evaluate the effects of single control variables on social innovation in isolation to other control variables, with no significant results detected. Similarly, individual one-way analysis of variance (ANOVA) tests (not shown) did not find any statistical differences in social innovation between any of the control variables and were subsequently not entered into the correlation matrix.

TABLE 1: Reliability results for the remaining organisational learning capability factors and the social innovation factor.

\begin{tabular}{lccc}
\hline Constructs & Number of items & $\begin{array}{c}\text { Average inter-items } \\
\text { total correlation }\end{array}$ & Cronbach's alpha \\
\hline OLC & 12 & 0.60 & 0.90 \\
$\begin{array}{l}\text { Knowledge } \\
\text { conversion }\end{array}$ & 4 & 0.61 & 0.80 \\
$\begin{array}{l}\text { Risk management } \\
\begin{array}{l}\text { Participative } \\
\text { decision-making }\end{array}\end{array}$ & 3 & 0.70 & 0.84 \\
$\begin{array}{l}\text { Organisational } \\
\text { dialogue }\end{array}$ & 3 & 0.59 & 0.75 \\
Social innovation & 7 & 0.55 & 0.70 \\
\hline
\end{tabular}

OLC, organisational learning capability. 
TABLE 2: Descriptives and correlation matrix for variables under study.

\begin{tabular}{|c|c|c|c|c|c|c|c|}
\hline Factor & Mean & SD & 1 & 2 & 3 & 4 & 5 \\
\hline Knowledge conversion & 5.37 & 1.08 & 1.000 & - & - & - & - \\
\hline Risk management & 5.47 & 1.23 & $0.635^{*}$ & 1.000 & - & - & - \\
\hline Participative decision-making & 4.82 & 1.58 & $0.539 *$ & $0.625^{*}$ & 1.000 & - & - \\
\hline Organisational dialogue & 5.59 & 1.08 & 0.462 & $0.557 *$ & 0.664 & 1.000 & - \\
\hline Social innovation & 5.64 & 0.97 & $0.712 * *$ & $0.677 *$ & $0.711^{* *}$ & $0.769 * *$ & 1.000 \\
\hline
\end{tabular}

SD, standard deviation.

*, Correlation is significant at the 0.05 level (two-tailed); **, correlation is significant at the 0.01 level (two-tailed).

TABLE 3: Linear regression results for the effect of knowledge conversion on social innovation (Hypothesis 1).

\begin{tabular}{llll}
\hline Variable & B & SE & $\boldsymbol{\beta}$ \\
\hline Intercept & $4.80^{* * *}$ & 0.45 & 0.00 \\
Risk management & 0.06 & 0.07 & 0.08 \\
Participative decision-making & 0.06 & 0.05 & 0.10 \\
Dialogue & 0.03 & 0.07 & 0.04 \\
Knowledge conversion & $0.48^{* * *}$ & 0.08 & 0.58 \\
ANOVA F & - & $21.32^{* * *}$ & - \\
$R^{2}$ & - & 0.45 & - \\
Adj $R^{2}$ & - & 0.43 & - \\
Akaike & - & -98.14 & - \\
Bayesian & - & -95.58 & - \\
Schwarz Bayesian & - & -80.71 & - \\
Prediction & - & 0.60 & - \\
\hline
\end{tabular}

ANOVA, analysis of variance; $B$, unstandardised parameters; SE, standard error; $\beta$, standardised parameters.

$* * *, p<0.01$.

To understand the nature of the relationship between the variables, a correlation analysis was conducted. Pearson product-moment correlation coefficients were calculated for each of the scales and are reported with levels of significance denoted in Table 2. The relatively strong $(r>0.60)$ and significant positive correlations between the OLC factors and the DV suggest initial support for all of the hypotheses in terms of positive associations between OLC factors and social innovation.

\section{Hypotheses testing}

The remaining hypotheses $(\mathrm{H} 1, \mathrm{H} 3, \mathrm{H} 5, \mathrm{H} 6)$ were tested using linear regression analyses. Scatter plots of residuals by regressor for each of the IVs were calculated independently for each hypothesis (not shown).

H1: For the influence of knowledge conversion on social innovation, results of the regression analyses (see Table 3) were statistically significant with an adjusted $R^{2}=0.43$ and a significant $F(21.32 ; p<0.001)$. These findings support the existence of a positive relationship between knowledge conversion and social innovation. Consequently, based on the statistically significant results, $\mathrm{H} 1$ is supported.

H3: The results of regression analysis in terms of the effect of risk management (see Table 4) on social innovation show a statistically significant adjusted $R^{2}=0.49$ and a significant $F(22.71 ; p<0.001)$, which means that the predictive and explanatory power of this model is fairly robust considering the amount of variance $\left(R^{2}=49 \%\right)$ explained in social innovation by this OLC factor. Consequently, based on the statistically significant results, H3 is supported.
TABLE 4: Linear regression results for the effect of risk management on social innovation (Hypnotises 3).

\begin{tabular}{llll}
\hline Variable & B & SE & $\boldsymbol{\beta}$ \\
\hline Intercept & $2.80^{* * *}$ & 0.41 & 0.00 \\
Knowledge conversion & $0.51^{* * *}$ & 0.08 & 0.61 \\
Participative decision & 0.03 & 0.05 & 0.04 \\
Dialogue & 0.00 & 0.07 & 0.00 \\
Risk management & $0.32 * * *$ & 0.09 & 0.44 \\
ANOVA F & - & $22.71 * * *$ & - \\
$R^{2}$ & - & 0.52 & - \\
Adj $R^{2}$ & - & 0.49 & - \\
Akaike & - & -112.70 & - \\
Bayesian & - & -109.94 & - \\
Schwarz Bayesian & - & -92.36 & - \\
Prediction & - & 0.54 & - \\
\hline
\end{tabular}

ANOVA, analysis of variance; $B$, unstandardised parameters; $\mathrm{SE}$, standard error; $\beta$, standardised parameters.

$* * *, p<0.01$.

TABLE 5: Linear regression results for the effect of organisational dialogue on social innovation (Hypnotises 5).

\begin{tabular}{llll}
\hline Variable & B & SE & $\beta$ \\
\hline Intercept & $2.80^{* * *}$ & 0.42 & 0.00 \\
Knowledge conversion & $0.43^{* * *}$ & 0.08 & 0.52 \\
Risk management & 0.04 & 0.07 & 0.06 \\
Participative decision-making & 0.06 & 0.05 & 0.11 \\
Organisational dialogue & 0.04 & 0.07 & 0.05 \\
ANOVA F & - & $25.63^{* * *}$ & - \\
$R^{2}$ & - & 0.44 & - \\
Adj $R^{2}$ & - & 0.42 & - \\
Akaike & - & -97.34 & - \\
Bayesian & - & -94.96 & - \\
Schwarz Bayesian & - & -82.81 & - \\
Prediction & - & 0.60 & - \\
\hline ANOVA, analysis of variance; $B$, unstandardised & parameters; SE, standard error; $\beta$, \\
standardised parameters. & & & \\
$* * *, p<0.01$. & &
\end{tabular}

H5: For the influence of organisational dialogue on social innovation, results of the linear regression model (see Table 5) were statistically significant with an adjusted $R^{2}=0.42$ and a significant $F(25.63 ; p<0.001)$. These findings support the existence of a moderate positive relationship between organisational dialogue and social innovation, as confirmed by the linear regression of the residuals of the IV on the DV. Consequently, based on the statistically significant results, $\mathrm{H} 5$ is supported.

H6: For the influence of participative decision-making on social innovation, results of the linear regression model (see Table 6) were statistically significant with an adjusted $R^{2}=0.44$ and a significant $F(25.63 ; p<0.001)$. These findings support the existence of a moderate positive linear relationship between participative decision-making and 
TABLE 6: Linear regression results for the effect of participative decision-making on social innovation (Hypnotises 6).

\begin{tabular}{llll}
\hline Variable & B & SE & $\boldsymbol{\beta}$ \\
\hline Intercept & $2.80^{* * *}$ & 0.48 & 0.00 \\
Knowledge conversion & $0.43^{* * *}$ & 0.08 & 0.52 \\
Risk management & 0.04 & 0.07 & 0.06 \\
Organisational dialogue & 0.06 & 0.05 & 0.11 \\
Participative decision-making & 0.04 & 0.07 & 0.05 \\
ANOVA F & - & $25.63^{* * *}$ & - \\
$R^{2}$ & - & 0.44 & - \\
Adj $R^{2}$ & - & 0.42 & - \\
Akaike & - & -97.34 & - \\
Bayesian & - & -94.96 & - \\
Schwarz Bayesian & - & -82.81 & - \\
Prediction & - & 0.60 & - \\
\hline
\end{tabular}

ANOVA, analysis of variance; B, unstandardised parameters; SE, standard error; $\beta$ standardised parameters.

$* * *, p<0.01$.

social innovation. Consequently, based on the statistically significant results, $\mathrm{H} 6$ is supported.

\section{Discussion}

The main purpose of this article was to determine how different organisational capabilities are related to social innovation. Recognising the need for empirical investigations into organisational aspects of social enterprises, this article is one of the first in the South African context to examine how dimensions of OLC may influence levels of social innovation. The study results show that the OLC dimensions of knowledge conversion, risk management, organisational dialogue and participative decision-making all have a significant and positive relationship with social innovation. Additionally, based on the regression results these OLC factors explain a significant amount of variance in levels of social innovation.

The study findings are in line with literature which indicates that the process of knowledge conversion evolving in social enterprises takes place through practice, active participation and interaction of local agents which leads to higher levels of innovations (Tandon, 2014). Organisational dialogue and participative decision-making represent the embedded nature of social enterprises whereby the organisation needs to understand the need of the community it aims to support, elaborate upon this information internally and convert it into organisational knowledge in order to develop innovative solutions. Furthermore, both organisational dialogue and participative decision-making affect levels of social innovation in terms of employee commitment which increases with engagement (Chalmers \& Balan-Vnuk, 2013).

The implications of these positive findings translate into recognising that managerial practices which promote social innovation tend to evolve across boundaries because of complexities of the cross-sector environment in which social enterprises operate and the context-specific solutions they need to implement (Tandon, 2014). Consequently, organisational dialogue is important for the management of social enterprises under such circumstances. Moreover, organisational dialogue and participative decision-making may be reinforced by the interaction of social enterprise actors with external stakeholders, through a complex structure of boundaries and agents who can bridge the gaps because of their diversity.

Considering the study was undertaken in an under researched emerging market context, South Africa, the adequacy of measures used in this study were first tested. The study established construct validity and reliability which adds to the growing knowledge base on the factor structure of OLC and social innovation. Additionally, the results also have contextual relevance where emerging economies provide a unique environment which offers the ability to obtain fresh insights and to expand the theory and our understanding of it by incorporating more contextualised considerations (Bruton, Ahlstrom \& Obloj, 2008). In this sense it is acknowledged that the social enterprise sector across sub-Saharan Africa is still highly influenced by local, international and bilateral political and economic decisions that often challenge the success of social-entrepreneurial initiatives aiming at systemic societal change (Karanda \& Toledano, 2012). In the African context, the survival of many social enterprises remains dubious (Gugerty, 2010). Past studies indicate that building a new, viable organisation is a challenging endeavour, and only some enterprises manage to reach the goal of running an operational business (Urban, 2008).

In terms of academic implications, this study is a starting point in filling the gap in the OLC and SE literatures which has largely neglected the effectiveness of African organisations.

Practically the implications of this study point to several areas of interest to managers and practitioners who need to be aware of the importance of the OLC dimensions in leveraging social innovations when considering that those who fund social enterprises are looking to invest in people with a demonstrated ability to create change, and the factors that matter most are the ability to learn and adapt (Urban, 2008). By focusing on dimensions of OLC it is anticipated that managers in social enterprises can configure and leverage knowledge conversion, risk management, organisational dialogue, and participative decision-making in ways that enable them to overcome the constraints of the complex and unpredictable environment in Africa and increase their levels of social innovation.

It is recommended that managers of social enterprises leverage their OLC in terms of knowledge conversion and organisational dialogue by identifying functional areas which they may impact - such as technology-enabled solutions to facilitate collecting data from the communities in which they operate. Additionally, adopting appropriate tools for risk assessments would support social enterprises in identifying their ideal level of risk taking versus innovativeness and could pave the way to provide measurable returns on investment to financial capital as well as returns on social investment. 
Managers should consciously establish organisational and individual determinants to create an environment supportive of sustainable innovation (De Jager, Muller \& Roodt, 2013). The development of creative and innovative thinking is not sufficient on its own to support sustainable innovation. As an HRM strategy, organisational learning always requires long-term commitment to be established, maintained and improved, while its value can only be demonstrated over time. Consequently, managers must recognise the need to invest in establishing HRM systems that promote organisational learning.

The study has several limitations of which the early stage of theoretical development of SE as a whole and its related measures in terms of OLC and social innovations remains open for further scrutiny. It is also recommended that scales used in this study be improved upon in future studies with constructs that capture the dynamic nature of the social innovation process. Another limitation of the article is that a cross-sectional design prevents demonstrating causation. Consequently, in future research using longitudinal research designs is required to examine the potential reciprocal links between the OLC and social innovation.

\section{Conclusion}

Building on the theoretical roots of organisational learning and innovation studies the study results support the hypotheses where the OLC dimensions of knowledge conversion, risk management, organisational dialogue and participative decision-making explain a significant amount of variation in levels of social innovation.

\section{Acknowledgements Competing interests}

The authors declare that they have no financial or personal relationships that may have inappropriately influenced them in writing this article.

\section{Authors' contributions}

B.U. wrote the article and was responsible for the conceptual design of the article. E.G. conducted the empirical work and interpreted the data emanating from the field work.

\section{References}

Alegre, J., Chiva, R., Gobert, D., \& Lapiedra, R. (2008). Organisational learning capability and product innovation: An empirical test on Spanish and Italian ceramic tile producers. Technovation, 28(6), 315-356. https://doi.org/10.1016/j. technovation.2007.09.003

Austin, J., Stevenson, H., \& Wei-Skillern, J. (2006). Social and commercial entrepreneurs: Same, different, or both. Entrepreneurship Theory and Practice, 30(1), 1-23. https://doi.org/10.1111/j.1540-6520.2006.00107.x

Bacq, S., \& Janssen, F. (2011). The multiple faces of social entrepreneurship: A review of definitional issues based on geographical and thematic criteria. Entrepreneurship \& Regional Development, 23(5-6), 373-403. https://doi.org/10.1080/08985626.20 11.577242

Barney, J.B. (2001). Resource-based theories of competitive advantage: A ten-year retrospective on the resource-based view. Journal of Management, 27(4), 643-650. https://doi.org/10.1177/014920630102700602

Bell, S.J., Whitwell, G.J., \& Lukas, B.A. (2002). Schools of thought in organisational learning. Journal of the Academy of Marketing Science, 30(1), 70-86. https://doi. org/10.1177/03079459994335
Bulut, C., Eren, H., \& Halac, D.S. (2013). Social innovation and psychometric analysis. Procedia-Social and Behavioral Sciences, 82, 122-130. https://doi.org/10.1016/j. sbspro.2013.06.235

Bruton, G.D., Ahlstrom, D., \& Obloj, K. (2008). Entrepreneurship in emerging economics: Where are we today and where the research should go in the future? Entrepreneurship Theory and Practice, 32(1), 1-14. https://doi.org/10.1111/ j.1540-6520.2007.00213.x

Cabrita, M.D.R., \& Vaz, J.L. (2005). Intellectual capital and value creation: Evidence from the Portuguese Banking Industry. Electronic Journal of Knowledge Management, 4(1), 11-20.

Cajaiba-Santana, G. (2014). Social innovation: Moving the field forward. A conceptual framework. Technological Forecasting and Social Change, 82, 42-51. https://doi. org/10.1016/j.techfore.2013.05.008

Chalmers, D.M., \& Balan-Vnuk, E. (2013). Innovating not-for-profit social ventures: Exploring the micro foundations of internal and external absorptive capacity routines. International Small Business Journal, 31(7) 785-810. https://doi. org/10.1177/0266242612465630

Chiva, R., \& Alegre, J. (2009). Organisational learning capability and job satisfaction: An empirical assessment in the ceramic tile industry. British Journal of Management, 20(3),323-340. https://doi.org/10.1111/j.1467-8551.2008.00586.x

Chiva, R., Alegre, J., \& Lapiedra, R. (2007). Measuring organisational learning capability among the workforce. International Journal of Manpower, 28(3/4), 224-242. https://doi.org/10.1108/01437720710755227

Cooper, D.R., \& Schindler, P.S. (2011). Business research methods. (11th edn.). New York: McGraw Hill International Edition.

Dacin, M.T., Dacin, P.A., \& Tracey, P. (2011). Social entrepreneurship: A critique and future directions. Organization Science, 22(5), 1203-1213. https://doi.org/ 10.1287/orsc. 1100.0620

Dees, J.G. (2007). Taking social entrepreneurship seriously. Society, 44(3), 24-31. https://doi.org/10.1007/BF02819936

Dees, J.G. (2009). Social ventures as learning laboratories, innovations, special edition for the World Economic Forum Annual Meeting. MIT Press Journal, 2(1), 11-15.

Dees, J.G., Emerson, J., \& Economy, P. (2001). Enterprising nonprofits: A toolkit for social entrepreneurs. New York: Wiley.

De Jager, C., Muller, A., \& Roodt, G. (2013). Developing creative and innovative thinking and problem-solving skills in a financial services organization. SA Journal of Human Resource Management, 11(1), 1-10. https://doi.org/10.4102/sajhrm. v11i1.502

Dover, G., \& Lawrence, T.B. (2012). The role of power in nonprofit innovation. Nonprofit Voluntary Sector Quarterly, 41(6), 991-1013. https://doi.org/10.1177/ 0899764011423304

Drucker, P.F. (1986). Innovation and entrepreneurship: Practice and principles. New York: Harper Collins.

Dutta, D.K., \& Crossan, M.M. (2005). The nature of entrepreneurial opportunities: Understanding the process using the $4 \mid$ organisational learning framework. Entrepreneurship Theory and Practice, 29(4), 425-449. https://doi.org/10.1111/ j.1540-6520.2005.00092.x

Easterby-Smith, M., Crossan, M., \& Nicolini, D. (2000). Organisational learning: Debates past, present and future. Journal of Management Studies, 37(6), 783796. https://doi.org/10.1111/1467-6486.00203

Escobar, J., Gutierrez, J., Gutierrez, M., \& Carlos, A. (2011). Social economy and the fourth sector, base and protagonist of social innovation. CIRIEC Espana, Revista de fourth sector, base and protagonist of social innovation.
Economia Publica, Social and Cooperativa, 73(1), 33-60.

Gugerty, M.K. (2010). The emergence of nonprofit self-regulation in Africa. Nonprofit and Voluntary Sector Quarterly, 39(6), 1087-1112. https://doi.org/10.1177/ 0899764010372972

Gunsel, A., Siachou, E., \& Acar, A.Z. (2011). Knowledge management and learning capability enhance organisational innovativeness. Procedia Social and Behavioral Sciences, 24(5), 880-888. https://doi.org/10.1016/j.sbspro.2011.09.012

Harding, R. (2006). Social entrepreneurship monitor, London: London Business School.

Hair, J.F., Black, W.C., Babin, B.J., \& Anderson, R.E. 2010. Multivariate data analysis: A global perspective. (7th edn.). Upper Saddle River, NJ: Pearson.

Helm, S.T., \& Andersson, F.O. (2010). Beyond taxonomy an empirical validation of social entrepreneurship in the nonprofit sector. Nonprofit Management and Leadership, 20(3), 259-276. https://doi.org/10.1002/nml.253

Holt, D. (2016). SASIE. South African Social Innovation and Entrepreneurship. Retrieved August 15, 2015, from http://www.sasieresearch.net/index.php/database

Hoogendoorn, B., \& Pennings, H.P.G. (2010). What do we know about social entrepreneurship: An analysis of empirical research? Erasmus Research Institute of Management: Rotterdam.

Innobasque. (2013). RESINDEX: Regional Social Innovation Index. A regional index to measure social innovation. Retrieved May 03, 2014, from http://www.innobasque. com/home. aspx?tabid=1163

Jaskyte, K. (2004). Transformational leadership, organisational culture, and innovation in non-profit organizations. Nonprofit Management and Leadership, 15(2), 153168. https://doi.org/10.1002/nml.253

Jaskyte, K., \& Dressler, W.W. (2005). Organisational culture and innovation in nonprofit human service organizations. Administration in Social Work, 29(2), 23-41. https:// doi.org/10.1300/J147v29n02_03

Jerez-Gómez, P., Céspedes-Lorente, J., \& Valle-Cabrera, R. (2005). Organisational learning and compensation strategies: Evidence from the Spanish chemical industry. Human Resource Management, 44(3), 279-299. https://doi.org/ $10.1002 / \mathrm{hrm} .20071$ 
Jiao, H. (2011). A conceptual model for social entrepreneurship directed toward social impact on society. Social Enterprise Journal, 7(2), 130-149. https://doi. impact on society. Social Enterpr

Karanda, C., \& Toledano, N., (2012). Social entrepreneurship in South Africa: A different narrative for a different context. Social Enterprise Journal, 8(3), 201-215. https://doi.org/10.1108/17508611211280755

Lave, J., \& Wenger, E. (1991). Situated learning: Legitimate peripheral participation Cambridge: Cambridge University Press. First published in 1990 as Institute fo Research on Learning report 90-001. https://doi.org/10.1017/СBO9780511815355

Lettice, F., \& Parekh, M. (2010). The social innovation process: Themes, challenges and implications for practice. International Journal of Technology Management, 51(1) 139-158. https://doi.org/10.1504/IJTM.2010.033133

Littlewood, D., \& Holt, D. (2013, November 12-13). Institutional framing of CSR and social entrepreneurship interactions in South Africa. Paper presented at ISBE Conference, Cardiff. Retrieved November 15, 2014, from http://www.isbe.org.uk

Mair, J., \& Marti, I. (2006). Social entrepreneurship research: A source of explanation, prediction, and delight. Journal of World Business, 41(1), 36-44.

Marques, J.F. (2007). The interconnectedness between leadership and learning: A reaffirmation. Journal of Management Development, 26(10), 918-932. https:// doi.org/10.1108/02621710710833388

McDonald, R.E. (2007). An investigation of innovation in nonprofit organizations: The role of organisational mission. Nonprofit and Voluntary Sector Quarterly, 36(2), 256-281. https://doi.org/10.1177/0899764006295996

Michelini, L., \& Fiorentino, D. (2012). New business models for creating shared value. Social Responsibility Journal, 8(4), 561-577. https://doi.org/10.1108/17471111 211272129

Mthanti, T., \& Urban, B. (2014). Effectuation and entrepreneurial orientation in hightechnology firms. Technology Analysis and Strategic Management, 25(9), 1-13. https://doi.org/10.1080/09537325.2013.850161

Newth, J., \& Woods, C. (2014). Resistance to social entrepreneurship: How context shapes innovation. Journal of Social Entrepreneurship, 5(2), 192-213. https://doi. org/10.1080/19420676.2014.889739

Nicholls, A. (2006). Introduction. In A. Nicholls (Ed.), Social entrepreneurship: New models of sustainable social change (pp. 1-35). Oxford: Oxford University Press.

Nicholls, A. (2011). Editorial: Social enterprise - At the forefront of rethinking business. Journal of Social Entrepreneurship, 2(1), 1-6. https://doi.org/10.1080/1 9420676.2011.566764

Nicholls, A. (2014). And in the end. Journal of Social Entrepreneurship, 5(1), 1-4. https://doi.org/10.1080/19420676.2014.888167

Nunnally, J.C. (1978). Psychometric theory. (2nd edn.). New York: McGraw-Hill.

Podsakoff, P.M., Mackenzie, S.B., Lee, J.Y., \& Podsakoff, N.P. (2003). Common method biases in behavioral research: A critical review of the literature and recommended remedies. Journal of Applied Psychology, 88(5), 879-903. https://doi.org/ 10.1037/0021-9010.88.5.879

Porter, M., \& Kramer, M. (2011, January/February). The big idea: Creating shared value, Harvard Business Review, pp. 1-17.
Pretorius, M., \& Le Roux, I. (2011). Successive failure, repeat entrepreneurship and no learning: A case study. SA Journal of Human Resource Management, 9(1), 1-13. https://doi.org/10.4102/sajhrm.v9i1.236

Ramsey, M., \& Barkhuizen, N. (2011). Organisational design elements and competencies for optimising the expertise of knowledge workers in a shared services centre. SA Journal of Human Resource Management, 9(1), 1-15. https:// doi.org/10.4102/sajhrm.v9i1.307

Rwigema, H., Urban, B., \& Venter, R. (2010). Entrepreneurship theory in practice. Johannesburg: Oxford University Press.

Sarasvathy, S.D., \& Venkataraman, S. (2011). Entrepreneurship as method: Open questions for an entrepreneurial future. Entrepreneurship Theory and Practice, 35(1), 113-135. https://doi.org/10.1111/j.1540-6520.2010.00425.x

Seelos, C., \& Mair, J. (2012). Innovation is not the holy-grail. Stanford Social Innovation Review, Fall, 44-49.

Simon, H.A. (1991). Bounded rationality and organisational learning. Organization Science, 2(1), 125-134. https://doi.org/10.1287/orsc.2.1.125

Tandon, A. (2014). Investigating learning in social enterprises: A boundary perspective. Social Enterprise Journal, 10(2), 155-172. https://doi.org/10.1108/ SEJ-05-2013-0022

Urban, B. (2008). Social entrepreneurship in South Africa: Delineating the construct with associated skills. International Journal of Entrepreneurial Behavior \& Research, 14(5), 346-364. https://doi.org/10.1108/13552550810897696

Urban, B. (2015). Evaluation of social enterprise outcomes and self-efficacy. International Journal of Social Economics, 42(2), 163-178. https://doi.org/ 10.1108/IJSE-03-2013-0071

Visser, M. (2009, May 11-14). Diagnosis organisational learning capability (DOLC). Paper presented at EURAM, Liverpool.

Watkins, K.E., \& Marsick, V.J. (Eds.). (1996). In action: Creating the learning organization. Alexandria, VA: ASTD Press.

Weerawardena, J., McDonald, R.E., \& Mort, G.S. (2010). Sustainability of nonprofit organizations: An empirical investigation. Journal of World Business, 45(4), 346356. https://doi.org/10.1016/j.jwb.2009.08.004

Weerawardena, J., \& Mort, G.S. (2001). Learning, innovation and competitive advantage in not-for-profit aged care marketing: A conceptual model and research propositions. Journal of Nonprofit \& Public Sector Marketing, 9(3), 53-73. https:// propositions. Journal of Nonprofit $\&$ (doi.org/10.1300/J054v09n03_04

Weerawardena, J., \& Mort, G.S. (2006). Investigating social entrepreneurship: A multidimensional model. Journal of World Business, 48(1), 21-35. https://doi. org/10.1016/j.jwb.2005.09.001

World Economic Forum. (2014). Outlook on the Global Agenda 2015. Retrieved February 28, 2015, from http://reports.weforum.org/outlook-global-agenda-2015/

Zoogah, D.B. Peng M.W. \& Woldu, H. (2015). Institutions, resources and organisational effectiveness in Africa. The Academy of Management Perspectives, 29(1), 7-31. https://doi.org/10.5465/amp.2012.0033 